\section{Mummification Technique in Ancient Egypt}

A PIECE of evidence bearing on the methods and apparatus in use in the processes of mummification in ancient Egypt, but which apparently has suffered neglect, has been rescued from the rest-house of the Department of Antiquities at Medinet Habu, where it has remained in the garden for many years, and has been placed in the Cairo Museum (The Times, June 6). It is a limestone table, on which the operation of embalming took place, and is officially described as unique. It measures eight feet five inches long by three feet four inches wide, and resembles the traditional form of the bed on which mummies were exhibited at funerals. Representations of the legs and feet of lions are carved in relief at the corners, and at the head were lions' heads similarly carved. A raised border surrounds the table, and at the foot, where the feet of the body lay, there is a sufficient depth to allow for the retention of several quarts of the embalming liquid. A small hole pierced at the end of the table allowed the liquid to be drained away from a semi-circular basin-like depression. The table is eleven and a half inches only in height, and it is therefore assumed that the embalmers worked in a squatting position.

\section{Astronomical Exhibits}

ON April 27 a number of astronomical exhibits were on view at the meeting of the British Astronomical Association held at Zion College. It would be impossible to describe all of these, but three were of sufficient interest to merit short notices in the May issue of the Association's Journal. Mr. D. A. Campbell showed an ingenious drive for small telescopes. This consisted of a sand-clock, a device at the base of the apparatus regulating the flow of wellsifted silver-sand. A piston of lead rested on the top of the sand, and this, as it sank, pulled a cord which finally actuated the driving shaft of the telescope. Dr. J. L. Haughton exhibited a microscope which measured star images. The main object of the instrument was to determine stellar magnitude by measuring the diameter of the photographic images, and for this purpose an accurately machined screw thread just over $1 \mathrm{~cm}$. in length was used. Mr. A. Coleman showed a solar eyepiece attachment, and has a fairly long description of the apparatus, which should be read by those who are interested in solar work. It minimizes certain disadvantages which are inherent in the usual combination of a solar diagonal with a suitable dark glass over the eyepiece.

\section{Iodine Educational Bureau}

ThE Nitrate Corporation of Chile Ltd. is organizing an Iodine Educational Bureau to promote the knowledge and use of iodine in the agricultural, medical and industrial fields. It collects all available scientific information in respect of iodine, and the information will be placed at the disposal of the medical profession and scientific agricultural circles, as well as commercial interests, including feeding stuffs manufacturers and livestock breeders. In addition, the Bureau will collaborate with scientific institutions in experimental research to extend the knowledge of iodine, with special reference to its use in human and animal nutrition. It will not engage in any selling activities. The Bureau will be under the direction of Dr. Francis C. Kelly, who has been associated with Sir John Orr for the past six years as deputy director of the Imperial Bureau of Animal Nutrition at the Rowett Research Institute in Aberdeen. Dr. Kelly is a graduate of the University of Aberdeen. Following two years in the Colonial Service as biochemist to the Medical Department of Kenya Colony, he became technical adviser to the Chilean Iodine Producers' Association in 1928. In 1930 he was appointed a member of the Iodine Estimation Subcommittee of the Medical Research Council of Great Britain. When the Imperial Bureau of Animal Nutrition was established in 1932, Dr. Kelly was appointed deputy director. $\mathrm{He}$ is also secretary of the international abstracting journal, Nutrition $A b$ stracts and Reviews. Dr. Kelly will become director of the Iodine Educational Bureau in September. His technical assistant will be Miss Ethelwyn M. Mason, of the New Zealand Department of Agriculture, who has been carrying out iodine research work at the Rowett Institute since 1934. The offices of the Iodine Educational Bureau will be at Stone House, Bishopsgate, E.C.2.

\section{'Dowtherm'}

DuRING the Great War, synthetic phenol was manufactured by sulphonating benzene, but a continuous process for vapour phase chlorination has been employed at the Dow Chemical Co.'s works in the United States for some time now. The chlorobenzene is afterwards hydrolysed with caustic soda and some diphenyl oxide is obtained as a by-product. Diphenyl oxide has a melting point of $27^{\circ} \mathrm{C}$. and in order to be useful as a commercial fluid for heat transmission it must not set solid in the piping when the plant is allowed to cool. Although diphenyl has a melting point of $70^{\circ} \mathrm{C}$, yet a eutectic mixture, known as 'Dowtherm', consisting of 26.5 per cent diphenyl with diphenyl oxide, melts at $12^{\circ} \mathrm{C}$. This compound can be used for heating purposes in a similar manner to steam but with the additional advantage of higher temperatures for the same pressure. The boiling point at atmospheric pressure is about $258^{\circ} \mathrm{C}$. and at $135 \mathrm{lb}$. per square inch gauge pressure it gives a temperature of $400^{\circ} \mathrm{C}$. against $181^{\circ} \mathrm{C}$. for steam. At $370^{\circ} \mathrm{C}$. the temperature can be controlled to within about $1^{\circ} \mathrm{C}$. by simply manipulating a throttle valve. The use of condensing vapour for heating results in considerable economy in plant design since the hot liquids in use hitherto have very low heat transfer coefficients. The vapours are not toxic, although leaks can be readily detected since the vapour is exceedingly pungent. It gives a means of accurately controlling the reaction temperature in the manufacture of dye intermediates and is used in the distillation of fatty acids and glycerine, the deodorization of edible oils, the evaporation of caustic soda, the processing of varnishes, the saponifying of greases and the melting of asphalts and bitumen. Owing to the low surface tension and viscosity of Dowtherm, all joints have to be made extremely care- 